\title{
Study of Measurement Technique of Resultant Resistance in the Underground Distribution System
}

\author{
Jun Yoshinaga Member (TEPCO) \\ Kuniaki Kawakami Non-member (TEPCO) \\ Hiroshi Yamada Non-member (Hasegawa Denki Industry Co., Inc.) \\ Toshiaki Hachijo Non-member (Hasegawa Denki Industry Co., Inc.) \\ Satoshi Uemura Member (CRIEPI)
}

Keywords: electric grounding resistance, resultant resistance, measuring equipment of ground resistance, underground distribution system, connecting earth

To realize the effective design and management of grounding resistances, it is necessary to establish an effective measuring technique such as resultant resistance. Especially on underground distribution system, it is too complex the connection of grounding system to understand the resultant resistance exactly by using of each grounding resistance measurement and calculation, etc.

Therefore, we proposed a new measuring technique which measures resultant resistance directly. Concretely, voltage is applied on two different circuits with auxiliary grounding electrode, and each current of the route on these circuits is measured. Based on these measured currents, the resultant resistance of the underground distribution system was obtained according to the equation of electric circuits. Moreover, based on this measurement technique, we developed the test model of the resultant measuring equipment (Fig. 1).

The verification to confirm accuracy of the measuring equipment was performed on electric circuits (equivalent resistance), practice lines (grounding earth) and commercial lines (grounding earth).

An experimental circuit and verified result are shown in Fig. 2 and Fig. 3 in the case on electric circuit.

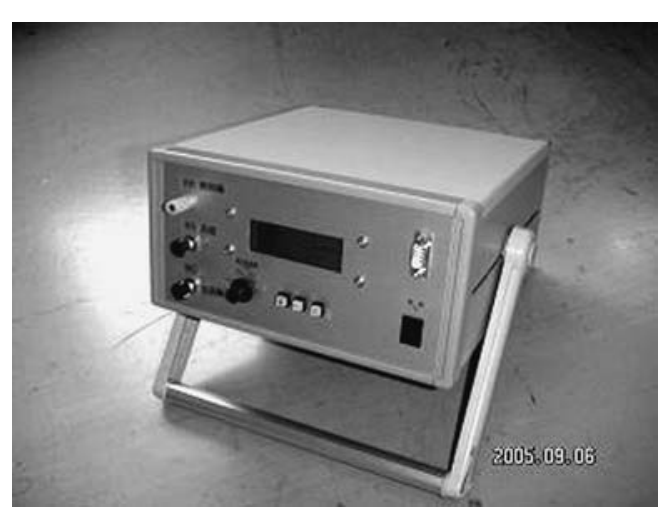

Fig. 1. Measuring equipment
As the measuring results by the equipment were in accordance with the calculation results of each resistor, the accuracy of the measuring equipment was confirmed.

Additionally, similar results were obtained also with the case on practice lines (test line in Akagi Testing Center, CRIEPI) and on commercial lines (in underground distribution system).

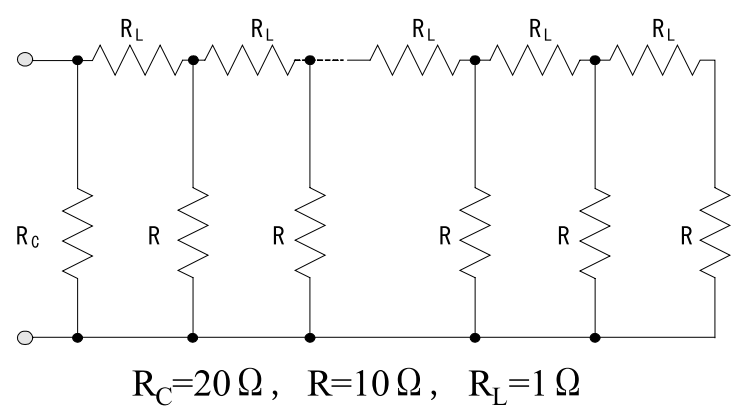

Fig. 2. Experimental circuit No.1 (Without earth conductivity)

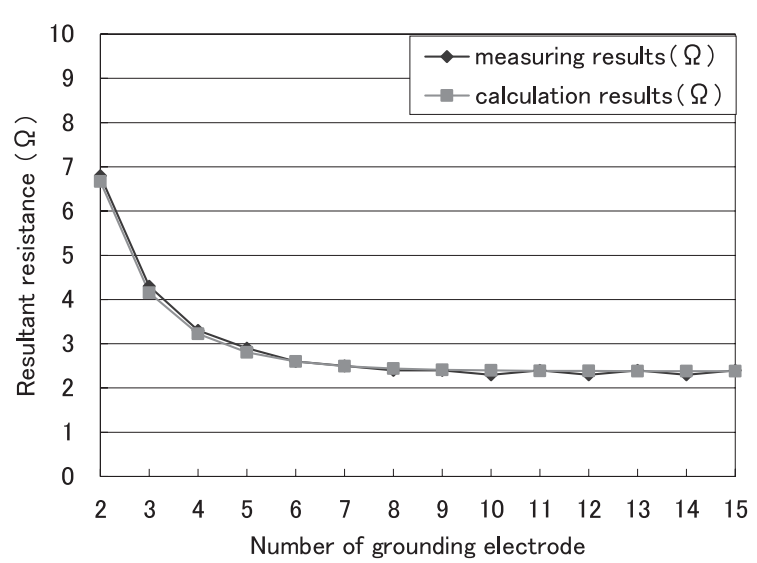

Fig. 3. Test results of electric circuit (Without earth conductivity) 


\section{地中配電系統における合成抵抗測定手法の検討}

$\begin{array}{lllll}\text { 正 員 吉永 } & \text { 淳* } & \text { 非会員 } & \text { 河上 } & \text { 邦明** } \\ \text { 非会員 山田 } & \text { 弘*** } & \text { 非会員 八条 } & \text { 敏明*** } \\ \text { 正 員 上村 } & \text { 敏**** } & & & \end{array}$

\section{Study of Measurement Technique of Resultant Resistance in the Underground Distribution System}

Jun Yoshinaga*, Member, Kuniaki Kawakami**, Non-member, Hiroshi Yamada***, Non-member, Toshiaki Hachijo $^{* * *}$, Non-member, Satoshi Uemura****, Member

To realize the effective management of grounding resistances, it is necessary to establish a measuring technique of resultant resistance. Especially on underground system, it is too complex the connection of grounding system to understand the resultant resistance exactly by using of calculation, etc.

Therefore, we propose a new measuring technique of resultant resistance. That is the way to apply the voltage on two different circuits with auxiliary grounding electrode, and to measure each current of the route on the circuits. Additionally, we produced a test measuring equipment, and performed the verification on electric circuits, practice lines and commercial lines.

キーワード：接地抵抗，合成抵抗，接地抵抗測定器，地中配電系統，連接接地

Keywords: electric grounding resistance, resultant resistance, measuring equipment of ground resistance, underground distribution system, connecting earth

\section{1. まえがき}

電力需要の高密度化への対応や商業地区など景観への配 慮といった観点から，現在，都市部を中心に地中配電系統 は増加しつつある。それに伴い変圧器や開閉器といった地 中配電用機器の施設数も増加している。これらの機器は歩

* 東京電力（株）電力流通本部配電部配電技術 $\mathrm{G}$

于 100-8560 東京都千代田区内幸町 1-1-3

Distribution Engineering Group. Distribution Department Power Network Division, TEPCO

1-3, Uchisaiwai-cho, 1-chome, Chiyoda-ku, Tokyo 100-8560

** 東京電力（株）東京支店大塚支社電子通信グループ

干 170-0004 東京都豊島区北大塚 2-33-17

Electronic Telecommunications Group. Tokyo Branch Otsuka Branch Office, TEPCO

3-6-8, Higashi Ikebukuro, Toshima-ku, Tokyo 170-0013

*** 長谷川電機工業（株） 技術部

干 661-0022 尼崎市尾浜町 3-29-3

Engineering Department, Hasegawa Denki Industry Co., Inc 3-29-3, Meishin-cho, Amagasaki 661-0022

**** (財) 電力中央研究所狛江研究所システム技術研究所需要家シス テム領域

干 201-8510 狛江市岩戸北 2-11-1

Customer Systems Sector, System Engineering Research Lab., CRIEPI

2-11-1, Iwado Kita, Komae 201-8511
道上に施設されることが多く，公衆が容易に接近すること が可能であり，場合によっては外箱に触れる恐れがあるこ とから，保安を目的として外箱に接地を施している ${ }^{(1)}$ 。

これら接地は抵抗值が低い程, 保安, 保護効果が高く, 望 ましい。しかしながら，一般に大地は異なる土質からなる 多層により形成されており，接地の施設場所や深さにより 大地導電率が異なる(2)。したがって, 電力会社では, 特に 岩盤などの大地導電率の低い土壤の地域では, 規定された 接地抵抗值を取得し, 維持するため費用と労力を費やして いる。一方, 昨今の電力自由化に伴い, 電力設備トータル でのコスト低減を指向する上では，接地に関わる費用も例 外ではなく，合理的かつ効率的に運用・管理を目指してい く必要がある。

東京電力の地中配電系統では, 地絡電流の分流を目的と して, 地中配電用機器の外箱接地が地中ケーブルの遮蔽層 を介して電気的に連接しており, 地絡等事故時の外箱の電 位上昇抑制が期待できる (図 1 参照)。ここで，公衆の保安 に関わる地絡・高低圧混触事故時の電位上昇は, 事故電流 の大きさと接地抵抗值の積で表される。一般に非接地系統 (配電系統) の地絡・高低圧混触時の事故電流の最大值は, バンクの対地静電容量より求まることから, 連接接地系の 場合，合成抵抗值を正確に把握することができれば，事故時 


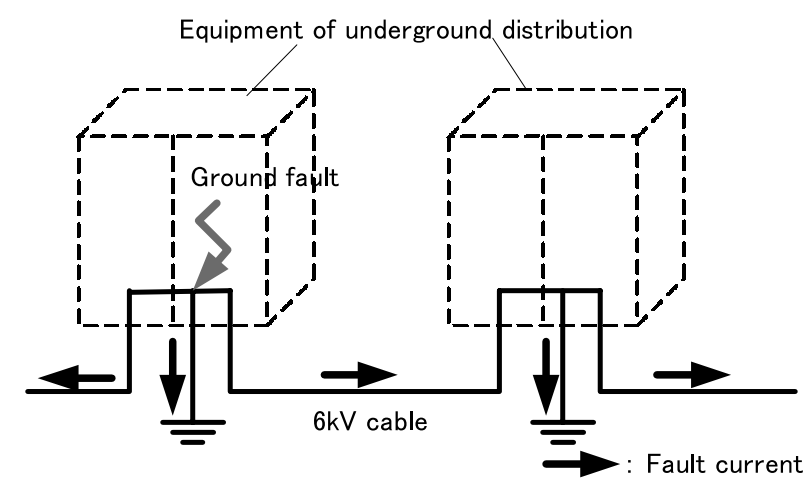

図 1 連接された接地系統

Fig. 1. Connected grounding system.

の機器外箱にかかる電位上昇の最大值を把握することがで きる。これにより，現在の単極管理に代わり合成抵抗管理 を行うことで，主目的である保安を担保できると共に，接 地管理の合理化が期待できる。

合成抵抗值を求める手法として，単極毎に接地抵抗を測 定し，並列計算する手法が考えられるが，地中配電系統で は, 接地系が複雑に接続されており，仮に電圧降下法を用い たとしても, 複雑な回路を構成するケーブル遮蔽層のイン ピーダンスをきちんと把握した上で，それらを見込むこと は難しい。また，測定した単極の接地抵抗值には僅かなが らも誤差が含まれていることから，複数の接地極を対象と する合成抵抗では，個々の測定誤差の積み上げとなり，合 成抵抗值を正確に把握することが難しい。

そこで，今回補助極を介した $2 つ の$ 異なる回路に電圧を 印加し, 印加電圧と各経路に流れる電流の測定值加合成 抵抗值を求める手法を提案した。手法の妥当性を確認する ために, JIS C1304 (接地抵抗計) (3) に基づく等価接地抵抗, 模擬線路および実フィールドでの検証試験を実施した。

\section{2. 合成抵抗測定手法の概要}

本手法では，大地を介した $2 つ の$ 異なる分流回路を形成 するため，系統接地とは別に補助接地極（ $\mathrm{R}_{\mathrm{b}} ）$ を施設し, はじめに測定対象機器の接地極 $\left(\mathrm{R}_{\mathrm{c}}\right)$ と系統側の接地 $\left(\mathrm{R}_{\mathrm{a}}\right)$ との間に電圧 (E) を印加する (図 2 参照)。印加電圧 $\mathrm{E}$ に より生じる電流は, 系統側 $\left(\mathrm{R}_{\mathrm{a}}\right)$ と補助極 $\left(\mathrm{R}_{\mathrm{b}}\right)$ のインピー ダンスの大きさに従い分流し， $\mathrm{R}_{\mathrm{a}}$ に流れる電流 $\left(\mathrm{I}_{\mathrm{a}}\right), \mathrm{R}_{\mathrm{b}}$ に流れる電流 $\left(\mathrm{I}_{\mathrm{b}}\right)$ および電源に戻る電流 $\left(\mathrm{I}_{\mathrm{c}}\right)$ を計測する。 ここで，電気回路上 $\mathrm{I}_{\mathrm{c}}$ は $\mathrm{I}_{\mathrm{a}}$ と $\mathrm{I}_{\mathrm{b}}$ の合算值となる。

次に図 3 に示す様に, $\mathrm{R}_{\mathrm{c}}$ を切り離した状態で $\mathrm{R}_{\mathrm{a}}$ と $\mathrm{R}_{\mathrm{b}}$ の間に電圧を印加し，回路に流れる電流 $\mathrm{I}_{\mathrm{d}}$ を求める。

それぞれ測定回路 $1 ， 2$ について，キルヒホッフの法則に 従い，以下の様な回路方程式が与えられる。

$$
\begin{aligned}
& E=R_{a} I_{a}+R_{c} I_{c} \\
& E=R_{b} I_{b}+R_{c} I_{c} \\
& I_{a}+I_{b}=I_{c} \cdots \\
& E=\left(R_{a}+R_{b}\right) I_{d}
\end{aligned}
$$

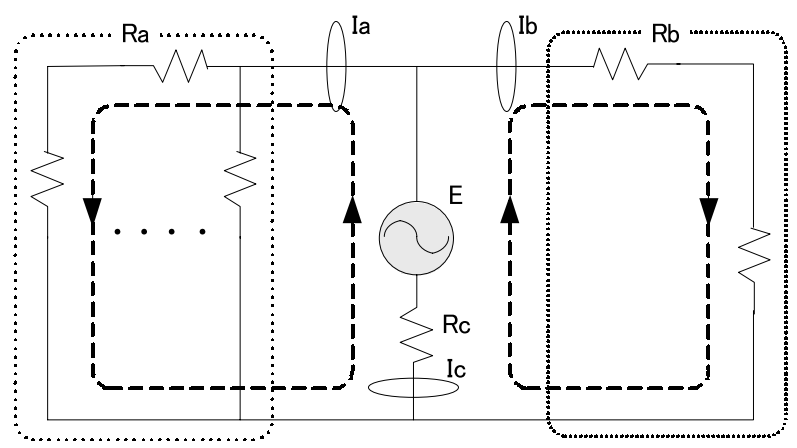

図 2 測定回路 1

Fig. 2. Illustration of the measuring circuit No.1.

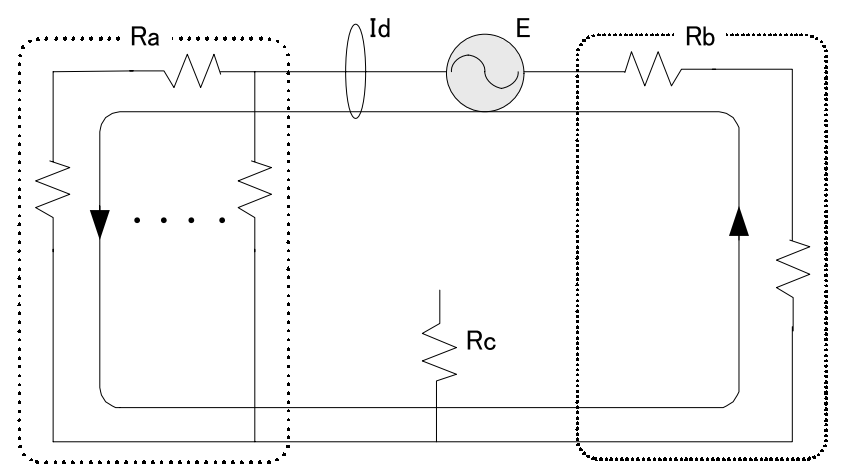

図 3 測定回路 2

Fig. 3. Illustration of the measuring circuit No.2.

$R_{a} \sim R_{c}$ は (1) (4) 式を解くことにより, 印加電圧 $(\mathrm{E})$ および測定される電流 $\left(I_{a} \sim I_{d}\right)$ から求めることができる。

$$
\begin{aligned}
R_{a} & =\frac{E}{I_{d}\left(1+\frac{I_{a}}{I_{b}}\right)} \\
R_{b} & =R_{a}\left(\frac{I_{a}}{I_{b}}\right) \cdots \\
R_{c} & =\frac{E-R_{a} I_{a}}{I_{c}} \cdots
\end{aligned}
$$

求めるべき合成抵抗值は， $R_{a}$ と $R_{c}$ の並列抵抗であるこ とから，(8) 式より求められる。

$$
R=\frac{1}{\frac{1}{R_{a}}+\frac{1}{R_{c}}} .
$$

\section{3. 合成抵抗測定器}

次に 2 項の測定手法を適用した合成抵抗測定器の開発を 行なった。作業性を考慮して携带型とし，電池で稼動する 方式とした。開発した試作器の主な仕様を以下に示す。

$\bigcirc$ 測定器 (試作器) の主な仕様

- 外寸： $260 \times 133 \times 280(\mathrm{~mm})$

- 重量：約 $4 \mathrm{~kg}$

- 印加信号電圧：1 V (交流)

- 印加周波数 : $200,300,400,500 \mathrm{~Hz}$ (可変) 


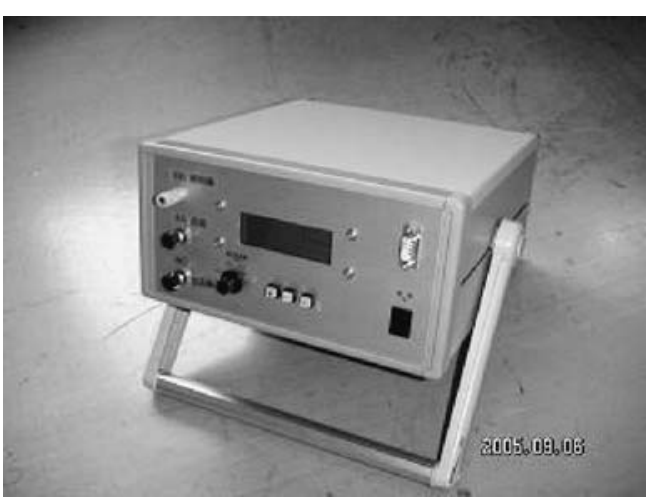

図 4 合成抵抗測定器外観図

Fig. 4. External of measuring equipment.

- 分解能： $0.1 \Omega$

- 合成抵抗測定範囲：0.2 50.0 $\Omega$

- 電源：単一乾電池 6 本 (アルカリ電池使用時に連続 使用 1 時間以上)

\section{4. 合成抵抗測定手法の妥当性検証}

本手法の妥当性を確認するために，電子回路を用いた等 価接地抵抗，模擬試験線路および実フィールド（商用線路） にて合成抵抗測定手法の妥当性検証試験を行った。

（1）等価接地抵抗（JIS C1304 に基づく）での検証 図 5 (接地抵抗およびケーブル遮蔽層の抵抗を模擬), 図 6

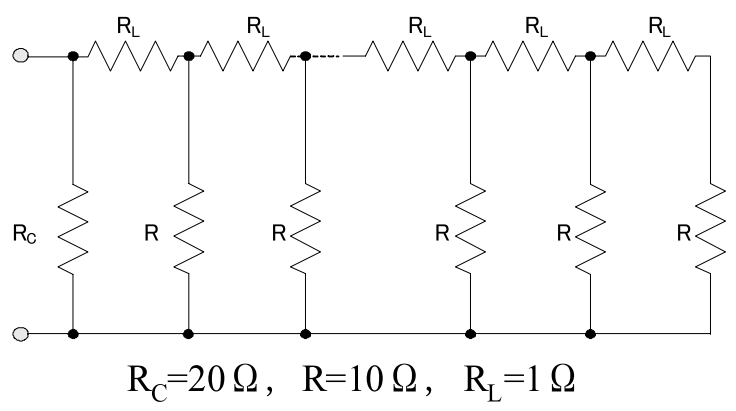

図 5 試験回路 1 (大地を $0 \Omega$ で模擬)

Fig. 5. Experimental circuit No.1 (Without earth conductivity).

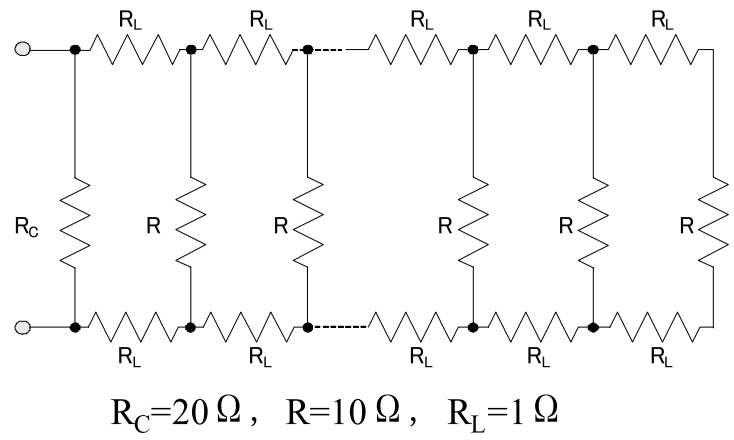

図 6 試験回路 2 (大地を抵抗で模擬)

Fig. 6. Experimental circuit No.2 (considering with earth conductivity).
（接地抵抗，ケーブル遮蔽層抵抗および大地抵抗を模擬）に 示す 2 つの回路を電子回路（抵抗素子の組み合わせ）によ り構成し，各素子の抵抗值を用いた合成抵抗值（計算）と 開発した合成抵抗測定器の測定值との比較を行なった。

接地極の並列数を変えた時の合成抵抗の測定值および計 算值を，それぞれ図 7 ，図 8 および表 1 ，表 2 に示す。

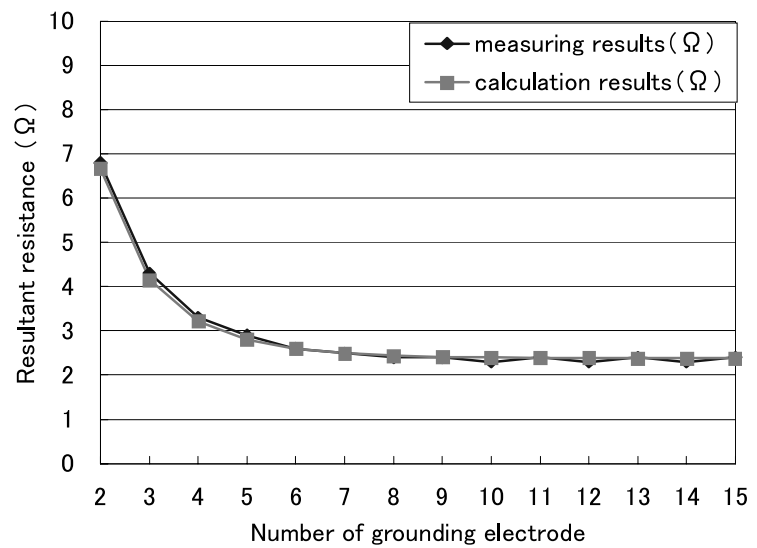

図 7 試験回路 1 の試験結果比較

Fig. 7. Test results of circuit No.1.

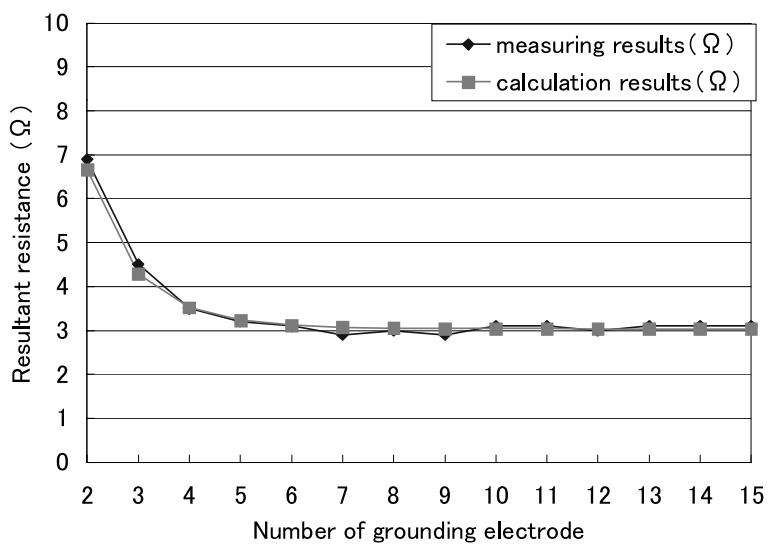

図 8 試験回路 2 の試験結果比較

Fig. 8. Test results of circuit No.2.

表 1 試験回路 1 の試験結果

Table 1. Test results of circuit No.1.

\begin{tabular}{|r|r|r|r|r|}
\hline $\begin{array}{c}\text { Number of } \\
\text { grounding } \\
\text { electrode }\end{array}$ & $\begin{array}{c}\text { measuring } \\
\text { results }(\Omega)\end{array}$ & $\begin{array}{c}\text { calculation } \\
\text { results }(\Omega)\end{array}$ & $\begin{array}{c}\text { differences } \\
(\Omega)\end{array}$ & errors $(\%)$ \\
\hline 2 & 6.8 & 6.7 & 0.13 & $2.0 \%$ \\
\hline 3 & 4.3 & 4.2 & 0.15 & $3.6 \%$ \\
\hline 4 & 3.3 & 3.2 & 0.08 & $2.4 \%$ \\
\hline 5 & 2.9 & 2.8 & 0.10 & $3.4 \%$ \\
\hline 6 & 2.6 & 2.6 & 0.00 & $0.0 \%$ \\
\hline 7 & 2.5 & 2.5 & 0.00 & $0.2 \%$ \\
\hline 8 & 2.4 & 2.4 & 0.04 & $1.7 \%$ \\
\hline 9 & 2.4 & 2.4 & 0.01 & $0.5 \%$ \\
\hline 10 & 2.3 & 2.4 & 0.10 & $4.1 \%$ \\
\hline 11 & 2.4 & 2.4 & 0.01 & $0.5 \%$ \\
\hline 12 & 2.3 & 2.4 & 0.08 & $3.6 \%$ \\
\hline 13 & 2.4 & 2.4 & 0.02 & $0.7 \%$ \\
\hline 14 & 2.3 & 2.4 & 0.08 & $3.4 \%$ \\
\hline 15 & 2.4 & 2.4 & 0.02 & $0.8 \%$ \\
\hline
\end{tabular}


表 2 試験回路 2 の試験結果

Table 2. Test results of circuit No.2.

\begin{tabular}{|r|r|r|r|r|}
\hline $\begin{array}{c}\text { Number of } \\
\text { grounding } \\
\text { electrode }\end{array}$ & $\begin{array}{c}\text { measuring } \\
\text { results }(\Omega)\end{array}$ & $\begin{array}{c}\text { calculation } \\
\text { results }(\Omega)\end{array}$ & $\begin{array}{c}\text { differences } \\
(\Omega)\end{array}$ & errors $(\%)$ \\
\hline 2 & 6.9 & 6.7 & 0.23 & $3.5 \%$ \\
\hline 3 & 4.5 & 4.3 & 0.21 & $5.0 \%$ \\
\hline 4 & 3.5 & 3.5 & 0.02 & $0.5 \%$ \\
\hline 5 & 3.2 & 3.2 & 0.03 & $1.0 \%$ \\
\hline 6 & 3.1 & 3.1 & 0.02 & $0.5 \%$ \\
\hline 7 & 2.9 & 3.1 & 0.17 & $5.6 \%$ \\
\hline 8 & 3 & 3.1 & 0.05 & $1.7 \%$ \\
\hline 9 & 2.9 & 3.0 & 0.14 & $4.7 \%$ \\
\hline 10 & 3.1 & 3.0 & 0.06 & $2.0 \%$ \\
\hline 11 & 3.1 & 3.0 & 0.06 & $2.0 \%$ \\
\hline 12 & 3 & 3.0 & 0.04 & $1.3 \%$ \\
\hline 13 & 3.1 & 3.0 & 0.06 & $2.0 \%$ \\
\hline 14 & 3.1 & 3.0 & 0.06 & $2.0 \%$ \\
\hline 15 & 3.1 & 3.0 & 0.06 & $2.0 \%$ \\
\hline
\end{tabular}

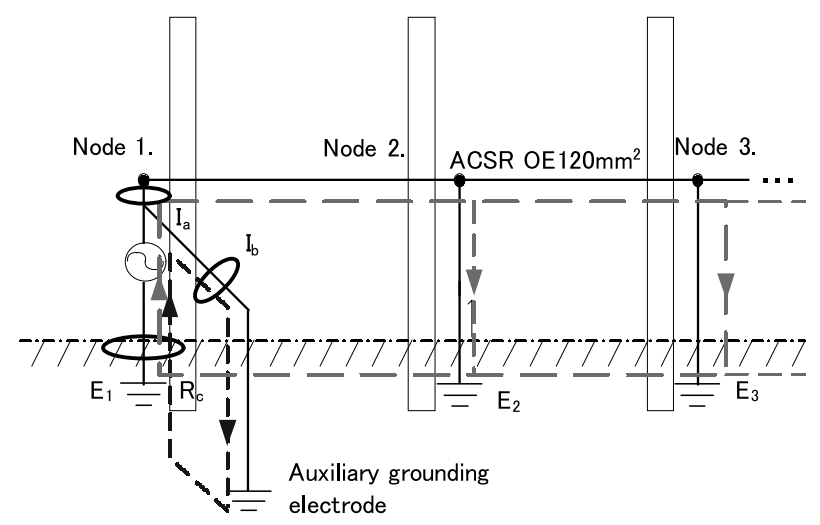

図 9 模擬試験線路

Fig. 9. Practice examination circuits.

試験回路 1，2 共に合成抵抗測定器の測定值と計算による 合成抵抗值を比較すると，接地極並列数の増加に従う合成 抵抗值低減の傾向抒よびその值は良く一致しており，その 差は最大でも $0.17 \Omega$ となり，JIS C1304（接地抵抗計）の 許容差 $\pm 0.5 \Omega$ （測定範囲 $0 \sim 10 \Omega ）$ を十分満たしている。

また，接地極数の増加に従い合成抵抗值は低減するもの の，極数がある程度増加すると一定值に収束している。こ の収束值は，ケーブル遮蔽層のインピーダンスと接地極の 抵抗值により変わり, 試験線路がある程度長くなると遮蔽 層のインピーダンスが大きくなり，合成抵抗值を求める際 にその值が無視できなくなることを意味している。

(2) 模擬試験線路での検証実際の接地極を用いて 大地を介した回路における合成抵抗測定手法の精度検証を 目的として, 電力中央研究所赤城試験センター内に試験線路 を設けて, 合成抵抗測定を実施した。試駼線路の概要を図 9 に示す。左端（Node1.）を合成接地抵抗の測定箇所とし, 右方向に最大 11 極（Node1. N Node11.) の接地極 $(20 \Omega \sim$ $80 \Omega$ 程度）を ACSR OE $120 \mathrm{~mm}^{2}$ を介して並列に接続し， 接地極を系統から切断，接続することで並列接地数を変え て検証を実施した。

本来であれば，（1）と同様に各極の抵抗值を求めて合成

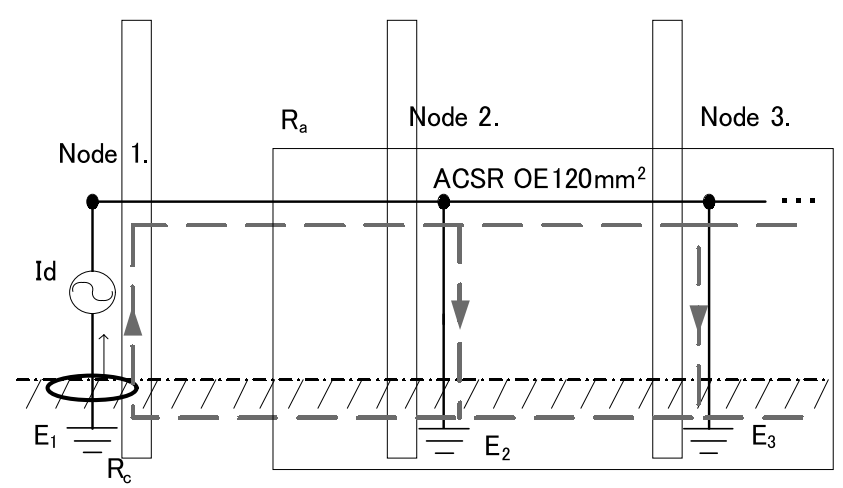

図 10 模擬試験線路（測定手法 3）

Fig. 10. Practice examination circuits (Measuring technique No.3).

（並列計算）した值と測定器の測定值を比較することが望ま しいが，実系統では対象の規模が大きくなるに従い，単極 毎の接地抵抗測定誤差の積み重ねが無視できなくなること や，接地極を繋いでいる遮蔽層等のインピーダンスを計算 上で正確に見込むことが難しい。ここでは以下の 3 つの測 定方法により測定値の比較を行なった。

測定方法 (1): 対象の接地系に安定電源で電圧を印加し, 各接地極を介して電源に戻る電流を校正 された電流計で測定し，合成抵抗值をキ ルヒホッフの回路方程式より求める方法

測定方法 (2)：測定方法（1）について, 試作した合成 抵抗測定器により直接測定する手法

測定方法 $(3)$ : 補助極を有しない回路 (Rc と Ra の間に 電圧を印加し，リターン電流より求める 手法)

測定方法（3）では，図 9 に示した回路において補助極 $\left(\mathrm{R}_{\mathrm{b}}\right)$ の代わりに当該極 $\left(\mathrm{R}_{\mathrm{c}}\right)$ を用いて, $\mathrm{R}_{\mathrm{a}}$ と $\mathrm{R}_{\mathrm{c}}$ の間に電 圧を印加して戻る電流（リターン電流）により求める方法 であり, 接地抵抗の考え方 $(\mathrm{V} / \mathrm{I})$ そのものに基づく方法で あるものの, 電圧/電流で得られた值は, $\mathrm{R}_{\mathrm{a}}$ と $\mathrm{R}_{\mathrm{c}}$ の直列抵 抗となる（図 10）。したがって, 合成抵抗值は測定より得 られた（V/I）の值から，電圧降下法など別の方法で求めた $\mathrm{R}_{\mathrm{c}}$ の值を引いて， $\mathrm{R}_{\mathrm{a}}$ を求めた後，(8) 式で計算する。 $\mathrm{R}_{\mathrm{c}}$ に 誤差が含まれる場合，分母・分子に誤差が生じるため，合 成抵抗值の誤差も大きくなる。

これら 3 つの測定方法の中で, 安定電源や電流計㧍よび 商用周波を除去するフィルタなど, 校正された測定器を用 いた方法である（1）が最も測定精度の面で期待できる。

系統の規模を変えた時の合成抵抗測定結果を図 11 およ び表 3 に示す。印加周波数は $200 \mathrm{~Hz}$ と $300 \mathrm{~Hz}$ を用いた。 接地極の連接規模を変えた際の測定方法 $(1) \sim(3)$ の測 定結果を比較したところ, 連接接地極数を变えた時の合成 抵抗値の低減傾向は良く一致した。ただし, 測定方法 (1) と（2）で用いた $50 \mathrm{~Hz}$ のフィルタ特性の僅かな相違によ り, $200 \mathrm{~Hz}$ に扔いてフィルタの影響が残る測定方法（1） 


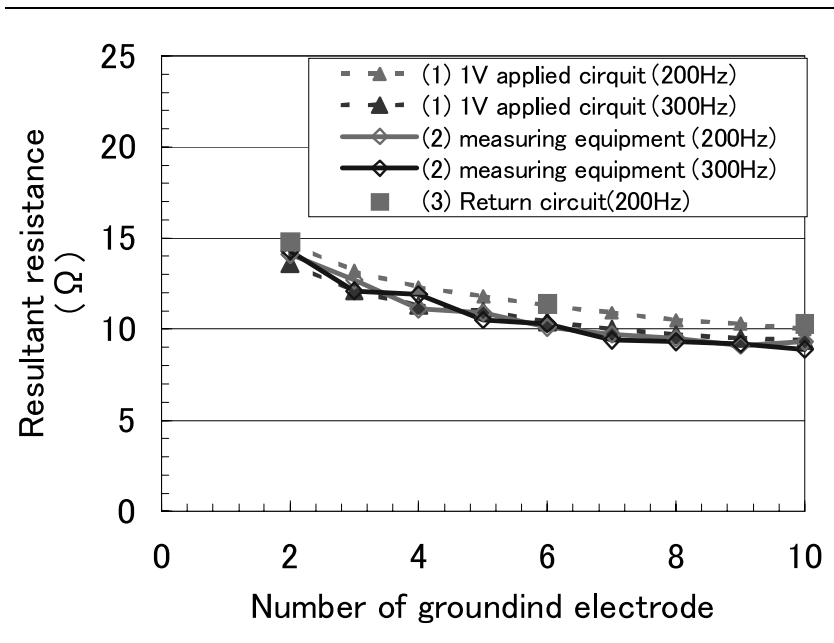

困 11 模擬試験線路の検証結果

Fig. 11. Result on the practice examination circuits.

\section{表 3 模擬試験線路の検証結果 ※)}

Table 3. Result on the practice examination circuits $\%$.

\begin{tabular}{|l|r|r|r|r|r|}
\hline & Frequency & $\begin{array}{c}\text { System side } \\
\text { resistance }\end{array}$ & $\begin{array}{c}\text { Auxilary } \\
\text { resisttance }\end{array}$ & $\begin{array}{l}\text { Concerned } \\
\text { electrode }\end{array}$ & $\begin{array}{c}\text { Resultant } \\
\text { resistance }\end{array}$ \\
\cline { 2 - 6 } & \multicolumn{1}{|c|}{$(\mathrm{Hz})$} & $\mathrm{R}_{\mathrm{A}}(\Omega)$ & $\mathrm{R}_{\mathrm{B}}(\Omega)$ & $\mathrm{R}_{\mathrm{C}}(\Omega)$ & \multicolumn{1}{c}{$\mathrm{R}(\Omega)$} \\
\cline { 2 - 6 } $\begin{array}{l}\text { (1) } 1 \mathrm{~V} \text { applied } \\
\text { circuit }\end{array}$ & 200 & 20.6 & 98.9 & 19.6 & 10.0 \\
\hline $\begin{array}{l}\text { (2) Measuring } \\
\text { equipment }\end{array}$ & 300 & 19.6 & 93.0 & 18.0 & 9.4 \\
\cline { 2 - 6 } & 200 & 18.8 & 91.9 & 18.3 & 9.3 \\
\hline (3) Return circuit & 200 & 18.0 & 86.1 & 17.7 & 8.9 \\
\hline
\end{tabular}

$※)$ The case of Node $1 \sim 11$

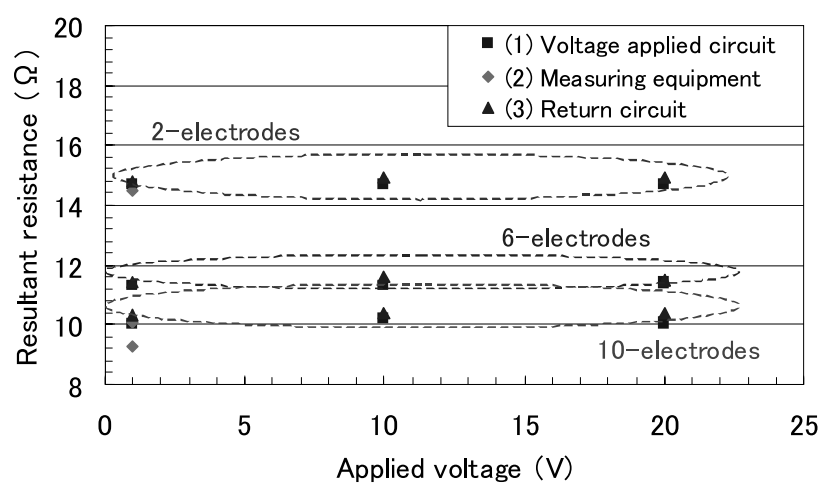

図 12 合成抵抗の電圧特性

Fig. 12. Voltage characteristics of resultant resistance.

の方が，この周波数では測定方法 (2)よりも僅かに高めの 值を示し，共にフィルタの影響をほとんど受けない $300 \mathrm{~Hz}$ では測定方法（1）と（2）の測定結果は良く一致した。ま た，同じフィルタを用いて測定した測定方法（1）と（3） は良く一致した。

次に測定方法（1）において，印加電圧を $1 \mathrm{~V} \sim 20 \mathrm{~V}$ ま で可変した時の合成抵抗検証を行なった。検証結果を図 12 および表 4 に示す。電圧を 1 ～20V まで変えても合成抵抗 值は連接接地極数に応じた一定の值を示した。これは，印 加する電圧の増加に対し，流れる電流がオームの法則に基 づく線形性が保たれていることを示している。
表 4 合成抵抗の電圧特性 ※)

Table 4. Voltage characteristic of resultant resistance ${ }^{*}$.

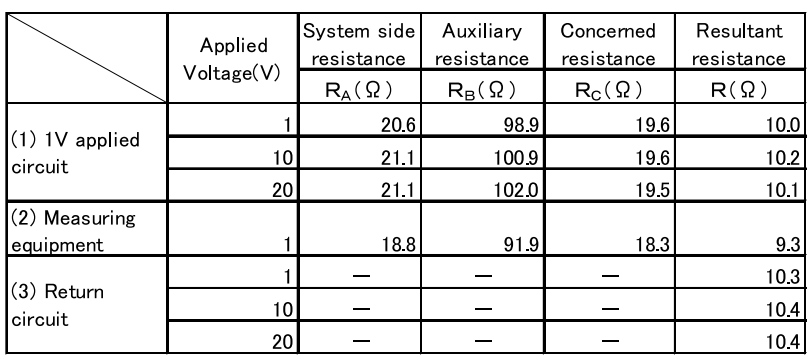

$※)$ The case of Node $1 \sim 11$

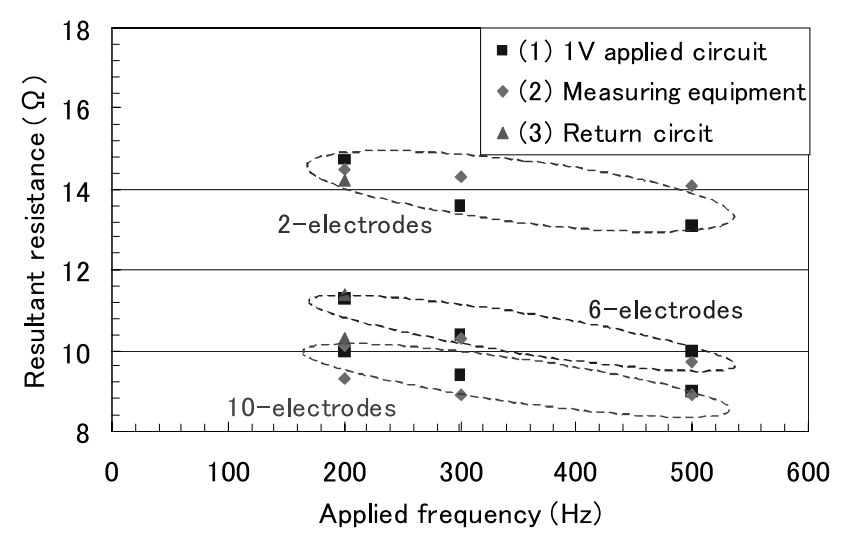

図 13 合成抵抗の周波数特性

Fig. 13. Frequency characteristics of resultant resistance.

\section{表 5 合成抵抗の周波数特性 ※)}

Table 5. Frequency characteristics of resultant resistance ${ }^{*)}$.

\begin{tabular}{|l|r|r|r|r|r|}
\hline & Frequency & $\begin{array}{c}\text { System side } \\
\text { resistance } \\
\mathrm{R}_{\mathrm{A}}(\Omega)\end{array}$ & $\begin{array}{c}\text { Auxiliary } \\
\text { resistance } \\
\mathrm{R}_{\mathrm{B}}(\Omega)\end{array}$ & $\begin{array}{l}\text { Concerned } \\
\text { resistance } \\
\mathrm{R}_{\mathrm{C}}(\Omega)\end{array}$ & $\begin{array}{c}\text { Resultant } \\
\text { resistance } \\
\mathrm{R}(\Omega)\end{array}$ \\
\hline \multirow{2}{*}{$\begin{array}{l}\text { (1) } 1 \mathrm{~V} \text { applied } \\
\text { circuit }\end{array}$} & 200 & 20.6 & 98.9 & 19.6 & 10.0 \\
\cline { 2 - 6 } & 300 & 19.6 & 93.0 & 18.0 & 9.4 \\
\cline { 2 - 6 } & 500 & 18.6 & 89.1 & 17.4 & 9.0 \\
\hline \multirow{2}{*}{$\begin{array}{l}\text { (2) Measuring } \\
\text { equipment }\end{array}$} & 200 & 18.8 & 91.9 & 18.3 & 9.3 \\
\cline { 2 - 6 } & 300 & 18.0 & 86.1 & 17.6 & 8.9 \\
\hline & 500 & 18.2 & 89.0 & 17.5 & 8.9 \\
\hline (3) Return circuit & 200 & - & - & - & 10.3 \\
\hline
\end{tabular}

$※)$ The case of Node $1 \sim 11$

次に印加周波数を $200 \mathrm{~Hz} \sim 500 \mathrm{~Hz}$ まで変えた時の合成 抵抗測定結果を図 13 および表 5 に示す。

計測結果から，前述した様に合成抵抗測定器と電圧印加 回路のフィルタ特性の違いにより，200 Hzでは僅かな差異 が生じているが，フィルタの影響が無視できる $300 \mathrm{~Hz}$ 以上 では，良い一致が得られた。ただし，印加周波数を高くす ると, ケーブル系統の亘長が長い場合, ケーブルの対地静 電容量およびリアクタンス成分が大きくなるため, 測定誤 差が増大する可能性がある。従って, 用いる印加周波数と してはできるだけ商用周波数に近く，かつフィルタの影響 が少ない $300 \mathrm{~Hz}$ を選定した。

（3）実フィールド線路での検証（2）と同様に東京 電力受け持ち区域内の実フィールドにて各測定方法の検証 


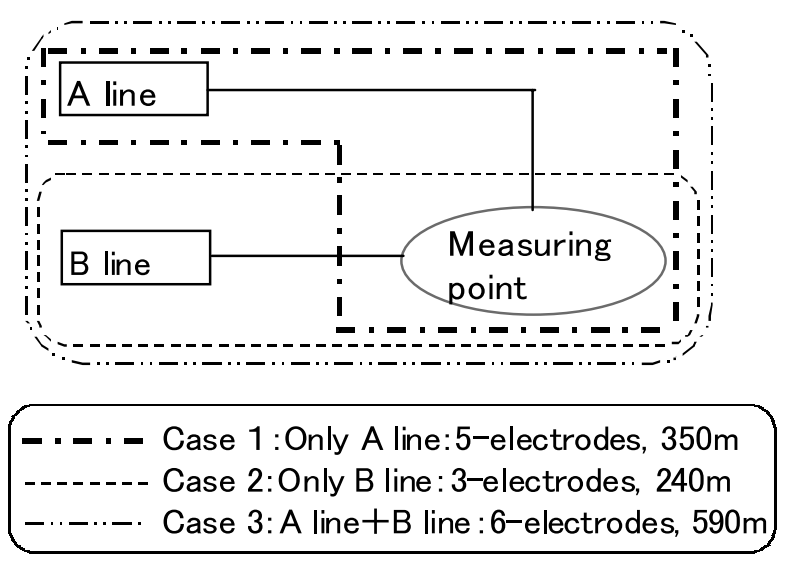

図 14 実フィールド試験線路 1

Fig. 14. Test circuit No.1 (Commercial lines).

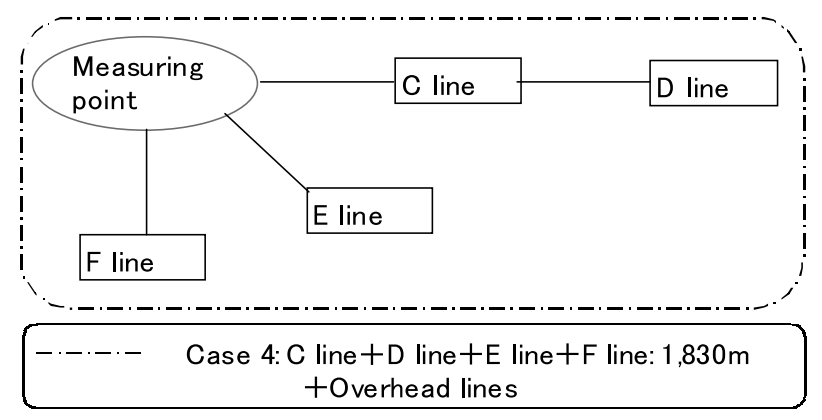

図 15 実フィールド試験線路 2

Fig. 15. Test circuit No.2 (Commercial lines).

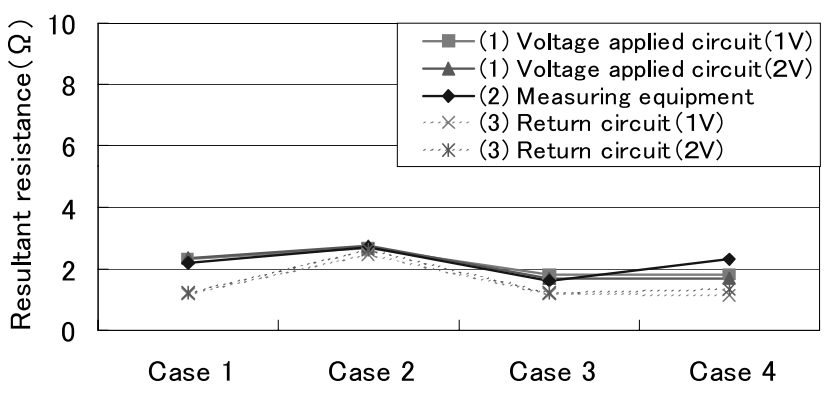

図 16 実フィールドでの検証結果

Fig. 16. Test results on commercial lines.

試験を実施した。地中化区域 2 箇所を選定し，1 箇所目は 連接接地極数を可変できる小規模かつ架空系統を全て切り 離した全地中系統（ケース 1３），2 箇所目は架空地中混在 の実規模系統（ケース 4）で検証を行なった。対象系統の 概要を図 14 , 図 15 に示す。

ケース 1〜4において，測定方法（1)〜（3）を用いた際 の合成抵抗測定結果を図 16 および表 6 に示す。接地系の 複雑な実フィールドにおいて, 系統規模（接地極の連接数） が变わっても，測定方法（1），（2）では接数増大に伴う合 成抵抗值低減の傾向およびその合成抵抗值は良く一致した。

特に，測定方法（1）では，印加電圧を $1 \mathrm{~V} ， 2 \mathrm{~V}$ と変え ても，合成抵抗值の差異は見られず，いずれのケースでも 測定方法（2）と良く一致した。
表 6 実フィールドでの検証結果の一例（ケース 3)

Table 6. An Example of test result on commercial lines.

\begin{tabular}{|l|r|r|r|r|}
\hline & $\begin{array}{c}\text { System side } \\
\text { resistance }\end{array}$ & $\begin{array}{c}\text { Auxiliary } \\
\text { resistance }\end{array}$ & $\begin{array}{c}\text { Concerned } \\
\text { resisatance }\end{array}$ & $\begin{array}{c}\text { Resultant } \\
\text { resistance }\end{array}$ \\
\cline { 2 - 5 } & \multicolumn{1}{c}{$\mathrm{R}_{\mathrm{A}}(\Omega)$} & $\mathrm{R}_{\mathrm{B}}(\Omega)$ & $\mathrm{R}_{\mathrm{C}}(\Omega)$ & \multicolumn{1}{c}{$\mathrm{R}(\Omega)$} \\
\hline (1) Voltage applied circuit(1V) & 2.3 & 55.5 & 8.1 & 1.8 \\
\hline (1) Voltage applied circuit(2V) & 2.1 & 57.5 & 8.5 & 1.69 \\
\hline (2) Measuring equipment & 2.1 & 57.4 & 7.9 & 1.6 \\
\hline (3) Return circuit(1V) & - & - & - & 1.18 \\
\hline (3) Return circuit(2V) & - & - & - & 1.23 \\
\hline
\end{tabular}

測定方法（3）では，接地系規模に応じた傾向は測定方 法（1），（2）と一致するものの, 合成抵抗值は全体的に やや低めの值を示した。これは, 別途 $\mathrm{R}_{\mathrm{c}}$ を求める際に, 周 囲環境により電圧降下法を用いることができず，クランプ 式で接地抵抗計を用いて求めたものの，この系統では連接 接地数が少なく, 測定した $\mathrm{R}_{\mathrm{C}}$ に高めの誤差が生じている ため，合成抵抗值にも誤差が生じていると考察できる。

また，架空・地中混在のケース（ケース 4) でも地中系 統の場合と同様の傾向を示し, 測定方法（1）, （2）の実 フィールドでの適用性を示している。

\section{5. あとがき}

本稿では，これまで困難であった地中配電系統の合成抵 抗測定について新たな手法の提案を行い, 同原理を採用し た試作器を開発した。

試作器の精度や妥当性を確認するために, 検証試験を行っ た。主な結果は以下の通りである。

（1）補助極を別途施設し，2つの異なる電気回路に電 圧を印加し，各経路を流れる電流を測定することにより， これまで困難であった地中配電系統の合成抵抗測定につい て，キルヒホッフの法則に基づく回路計算から合成抵抗を 求める測定手法の提案を行った。

（2）同原理を採用した試作器を開発し, 測定器の精度 および妥当性を検証するため, 電子回路を用いた等価回路 による試験を実施した。その測定結果と計算結果 (真值)を 比較すると, 接地極数 (等価抵抗模擬) を増やしていった時 の傾向およびその值が良く一致することが確認できた。誤 差は最大でも $0.17 \Omega$ であり, JIS C1304 (接地抵抗計) の許 容差 $\pm 0.5 \Omega$ （測定範囲 $0 \sim 10 \Omega ）$ を十分満たしており，合 成抵抗測定器の妥当性が確認された。

（3）実際の接地極に対する合成抵抗測定器の妥当性を 検証するため, 電力中央研究所での試験線路（2極～11 極 $)$ および東京電力受け持ち区域内の地中化系統で, 検証試験 を実施した。接地極の連接数を変えて, 回路方程式に基づ く手法, リターン回路での検証結果を比較したところ, 連 接数に応じた合成抵抗值の傾向およびその值は概ね一致し ていることが確認できた。

最後に，本試験を実施するにあたり多大なるご協力を頂 いた関係者各位に感謝の意を表します。

(平成 17 年 10 月 24 日受付, 平成 18 年 2 月 20 日再受付) 


\section{文献}

（1）経済産業省原子力安全·保安院編：解説 電気設備の技術基準（第 11 版), 文一総合出版 (2003)

（2）川瀬太郎・高橋健彦：図解接地技術入門, オーム社 (1986)

（3）「接地抵抗計」, JIS C 1304, 日本工業標準調查会 (1995)

吉 永淳（正員） 1968 年 10 月 2 日生。1994 年 3 月大阪 大学大学院工学研究科生産加工工学専攻博士課程 前期修了。同年 4 月東京電力（株）入社。主とし て，配電系統に関する業務㧍よび研究に従事。現 在，同社配電部配電技術グループ主任。

河 上 邦 明

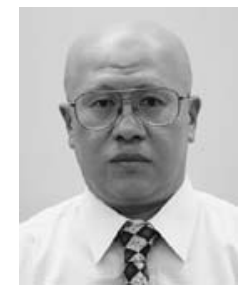

山田

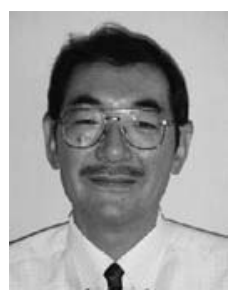

八条敏 明

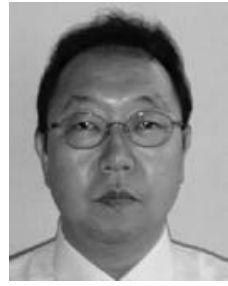

（非会員） 1961 年 3 月 11 日生。1986 年 3 月大 阪工業大学工学部電子工学科卒業。1992 年 3 月 長谷川電機工業（株）入社。主として，送配電系 統用測定機器の研究，開発に従事。現在，同社技 術部担当課長。

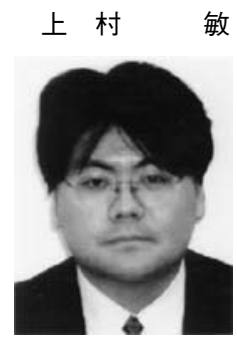

敏（正員） 1968 年 4 月 18 日生。1994 年 3 月東京 工業大学理工学研究科電気電子工学専攻修士課程 終了。1997 年 4 月（財）電力中央研究所入所。現 在, 同所システム技術研究所需要家システム領域 主任研究員。主として, 配電系統の運用, 保護抒 よび分散型電源の系統連系に関する研究に従事。 